\title{
A STUDY OF SOCIOLOGY ON OUTSOURCING PRACTICE
}

\author{
Oleh:
}

Shermina Oruh: shoruh68@gmail.com

Andi Agustang: andi.agustang@unm.ac.id

\begin{abstract}
This research aims to analyze and explain hegemonic social relation in outsourcing practice in Makassar city concerning; (1) the causes of hegemonic social relation among actorss of user, provider and laborer, (2) the patterns and types of hegemonic social relation, and (3) the social and economic impacts of hegemonic social relation. This research employs the kind of descriptive research with qualitative approach. The result of this study gives more clear and deeper describe concerning many kinds of meaning which are behind the fact so that this research uses phenomenological method with perspective interpretative. While the phenomenon is outsourcing practice in Makassar city. The result of this research shows that the social relation among actors user, provider and laborer in outsourcing practice in Makassar city is not just an ordinary economic relation but it is a veiled power relation which constructs a hegemonic social relation. The hegemonic social relation is caused by some factors, namely; (a) unlimited authority owned by user, (b) closed management applicated by provider, (c) laborer's less bargaining position, and (d) lost government intervention. The four causes create the patterns and types of hegemonic social relation in outsourcing practice, namely; (1) absolute hegemony by user toward provider and laborer like, job outsourcing (job transfer), job responsibility transfer, and the use of manpower and more work time, (2) semi-hegemony by provider toward laborer by action of transferring laborer from one user to others, and (3) absolute hegemonized toward laborer by both user and provider through the use of laborer's work power by user, outsourcing of laborer from one user to others done by provider. the fact, outsourcing practice benefits the captilists (user and provider), on the contrary, it harms the laborer.
\end{abstract}

\section{Key words: social relation, hegemony, outsourcing}

\section{Introduction}

Social relation constitutes a manifestation of social interaction among individuals or groups in a society which can hold anytime and anywhere. It means that the social relation exists everywhere including in outsourcing arena. This relation is not 
separated from political interest, economic interest, social interest and cultural interest. These all constitute the motives which encourage each actor to interact one and each other. The social relation has potency of power so that it creates power relation which according to Foucault (1987) [1] that the power relation consists of three types, namely; (1) power relation as a trategic play among the free parties, (2) power relation as a domination, and (3) power relation as government. The power relation in the strategic plays describes the relation of inter-partnert where the power of actor has freedom for selecting and influencing. On the contrary, the type of domination relation points toward asymmetric power relation where there are subordinated actors and only have a little space for acting freely. While on the type of governmental power relation exists between the strategic plays and domination. The accentuation of government concept is instructions and control of action combination. Furhter Foucault (in Afandi, 2011) [2] stated that, where there is a social relation there is a power and on the contrary, where there is a power there is a social relation.

Hegemony is a manifestation of power in social relation among actors involved. According to Gramsci (1978) [3] that, hegemony covers the cultural and ideological in which the authority groups perform or perpetuate their power on society through consencus of the dominated parties. To Gramsci, such a domination of power is struggled to get the public acceptance. The hegemony is used not only for elaborating the relation of inter-class as Marx stated, but also the larger social relations including the actors' social relation in outsourcing arena.

Outsourcing practice has become a reseach object which has been done by many researchers. According to Geishecker (2004) [4] that, there are different wage which is received by laborer working under the implementation of international outsourcing system in the companies which his research focuses on in German. The proves of his research are the the laborers lowskilled workers get lower wage as the effect of outsourcing while the laborer with high-skilled workers get high wage.

Jangyang Goo, and et al (2006) [5] have investigated the factors which influence the relationship duration of information technology outsourcing. According to their research that, Social theories have been employed in IT outsourcing research to address the issue of managing inter-organizational ties in the outsourcing relationship. Most of this research deals with inter-organizational dyads that help firms cope with resource scarcity while achieving goals for reducing vulnerability and uncertainty and for maximizing their own autonomy and independence. Studies using the social perspective have drawn upon social exchange theory to understand the outsourcing relationship as a dynamic process that evolves through specific sequential interactions in which two 
participants carry out activities for one another and exchange valuable resources. An important finding from the social exchange perspective is that vendor-client relationship are terminated or continue based on the satisfaction of relationships. They create some perspective based on the statement above namely; (1) social theories have been employed for the research of outsourcing in the field of information technology and shows that, in outsourcing, there is a relation inter-organization. Mostly researches are concerning inter-organizations which help the company to overcome the lack of resources when reaching the aim of susceptibility and uncertainty for maximizing the authonomy and the freedom, (2) the study using the social perpective has employed the social exchange theory to understand the outsourcing relationship as a dynamic process which develop through a chronological specific interaction in which two parties hold activities of valuable resources exchange one and each other, (3) an important discover of social exchange perspective is that the relationship between vendor - client is ended or continued by the satisfaction of relationship.

Greaver II (in Yasar, 2012) [6] stated that, "Outsourcing is the act of transferring some of a company's recurring internal activities and decision rights to outside provider, as set forth in a contract. Because the activities are recurring and a contract is used, outsourcing goes beyond the use of consultants. As a matter of practice, not only are the activities transferred, but the factor of production and decision rights often are, too. Factors of production are the resources that make the activities occur and include people, facilities, equipment, technology and the other asset. Decision rights are the responsibility for making decision over certain elements of the activities transferred."

While according to Beaumont and Sohal (2004) [7] that, "the use of outsourcing is becoming more sophisticated; more organizations are outsourcing responsibility for business processes. Further, they emphasize that, Outsourcing is defined as having work that was formerly done inside the organization performed by an external organization. The vendor (hereafter the outsourcer and outsource are, respectively, referred to as vendor and client) may be an independent entity ora wholly owned subsidiary.

At the othe hand, Martinsons (1993) [8] stated that, "Information systems outsourcing is the act of subcontracting all or parts of the Information system function to an external vendor as an alternative to relying solely on in-house resources and capabilities. An outsourcing vendor, with highly specialized and technical employees, assumes a contractual obligation for the organization's information systems and their operation. This activity was traditionally limited to the subcontracting of data processing activities, frequently called facilities management. The relationship 
between the vendor and the organization had an arms-length status. In the meantime, the result of research from Tjandraningsih et al (2010) [9] find that the relation practice of work contract and outsourcing indicate the essence of policy and practice of LMF which is more profitable for the company and it is a loss for the laborer. the result of their research indicates the proves that positive assumptions of flexible work market are not proved and even the condition is vice versa. The practice of flexible work market through the relation of work contract and outsourcing has created exploitative, discriminative, degradative, and fragmented work conditions, and it also effectively weakens the power of laborer organizations.

While, according to the research result from Child and Mollering (in Juan Li, 2011) [10] stated that, "Outsourcing is defined as contracting tasks to an external entity. Transferring business activities to external actors poses two significant challenges for MNCs: business partners' opportunism and local market uncertainty. Literature on control has clearly established that control facilitates coordination of inter-organizational exchanges in uncertain business environments." The meaning of the elaboration above that, outsourcing practice indicates the aspect of work contract to external hand and outsourcing action or transferring of business activities to external actors. On the other words, the action envolves the third hand which can be understood as the the provider company of manpower. This condition constitutes two significant levels of national multi corporation covering; opporunism of uncertainty of local market.

Outsourcing constitutes an arena which combines social relation with hegemony so that creates a veiled power relation among actors that involve in it. Outsourcing practice emphasizes cost of production, free market competition which aim to create the economizing of cost in financing human resources that are used in a certain company. Outsourcing practice is the form of transfer action in which its application involves the actors namely, user, provider and laborer. Silaban (2009) [11] stated that the outsourcing is the real form of flexibility principle of work market which can be found in almost the whole part in production process. Thus, there is a competition among laborers to get the work chance. For the capitalists, this condition also gives them opportunity to execute exploitation action to the laborers as the form of capitalism system which according to Marx (in Suseno, 1999) [12] stated that, people do not work freely and universally but they are forced to work as the requirement for living. So the work does not develop but isolate the human beings both from themselves and others.

In an ideal context, outsourcing practice is supposed to use the human resources so that the unemployment can get job as their living resource. In other words, the laborers can be absorbed to have living resource by the gift of wage. Thus, they become productive 
human being. This means that outsourcing becomes a practical tool which can assist the government for fighting the joblesses. Therefore, it is important to build a type of harmonious relationship among the company (businessmen), government and laborers

The harmonious relation meant is the creation mutual profitable work relation through the medium of outsourcing. The businessmen employ the laborers to be productive human being for both themselves and their family including for the provider company and the user company. Besides, The government should undertake its function for controlling the outsourcing practice and making regulation as the basis of outsourcing application system. This thing is important in order that the work relation between the company (user and provider) and laborer does not create the type of exploitation relation.

Without laborers, the company will not be productive and developing, on the contrary, the laborers will not be able to sustain themselves and their family without being employed by the company. So they have mutual relationship. The laborers can be creative in developing their potency through the job. Through the job, the human being proves himself as a social creature. It is imposible for everyone produces anything they need by themselves. To meet our need, we depend on the result of the other one's job. So does the other need our job result.

But in reality, outsourcing practice shows some problems. The cause is the work relation among the actors of user, provider with laborer do not apply symmetrical relation (business partnert). The laborers work and get wage less than they should receive, they work without enough financial support and without better career in the future, and also longer work time. The lost government intervention also causes the capitalists' actions (user and provider) to be free for dominating the laborers through the use of regulations which they made and must be agreed together. The problems then appear which are caused by the actions of user and provider that aim to gain cost efficiency and bigger profit accumulation. At the other hand, the laborers are exploited because they spend a lot power and time to get wage less than they should receive

In practice of social relation among actors of user and provider, the laborers just become the instrument or tool of transaction. The laborers are not involved in making decisions concerning the action of laborer transfer including the work responsibility transfer between user and laborer. In outsourcing practice, the actor of user becomes the absolute hegemonizer toward both provider and laborers. The user company becomes the determiner that determine the execution of work relation with the provider company. In other words, to execute the work relation or not, it is the right of the user. Besides, the user has the right to use the power and time of the laborers fully. At the other hand, the actor 
of provider also dominates the laborers because the provider determines whether the laborers can work or can not work in user company. Through the provider's service, the laborers can be employed in the user company as the place of work activities for the laborers and consequently, the laborers' wage is managed by the provider. The laborers must give some of their wage to the provider as repayment of service.

The hegemonic social relation in outsourcing practice in Makassar city gives a clear picture that the laborer becomes the absolute hegemonized party by both user and provider. The phenomena also describes the types and forms of hegemonic social relation which construct the social economic impacts toward both the hegemonizer parties and the hegemonized one.

\section{Materials and Methods}

The kind of research which is used in this research is descriptive research with qualitative approach. The result of analysis of this reseach gives a deep and clear picture on some kinds of meanings behind the facts so that it is used phenomenological method with interpretation perspective, while the phenomena is outsourcing practice in Makassar city. The design of this research is based on the paradigm which is described on the character of problem and suitability of assumption. The use of research paradigm constitutes a strategy which is doned before the researcher holds the field research. Before designing the research, the researcher tries to know about the paradigm of research which will be used. The urgency is the main function of research paradigm is to form research method. While the factor of main consideration in choosing paradigm is the character of problem and suitability of assumption which are built by the researcher. Therefore, the paradigm which is used in this research is constructivism paradigm with phenomenological method. The basis is the social relation in outsourcing practice is constructed by the actors through social practice and it is not formed by itself (natural). This thing is emphasized by Guba and Lincoln (1994) [13] that, constructivism Paradigma is based on the assumption that, basically social reality is not formed by itself (natural) but it is constructed by actors through the process of social practice. The construksionists do not agree with the opinion that all kinds of essencial things are preceeded the process of social determination. Guba and Lincoln further said that, positivism and postpositivism have been failure to express the reality. It is the time for the postivism and postpositivism to be reconstructed constructively. The main focuses of this research is repeated social practices which are meant that they have constructed the power relation through hegemonic social relation in outsourcing practice among actors of user, provider and laborer. Therefore, this reseach is designed toward the studies of social 
sciences, particularly economic sociology.

The attention and main interpretation in this research are on the meaning and daily subjective experiences in social relation among the actors of user, provider, and laborer that have constructed power realtion through hegemonic social relation in outsourcing practice in Makassar city.

This thing also becomes the basis of interpretation and explanation concerning hegemonic social relation in outsourcing practice covering its causes namely; unlimited authority by user, closed managemen application by provider, less bargaining position of laborer, and loss government intervention. The interpretation and explanation about patterns and forms of hegemonic social relation are also described through absolute hegemony by user, semi-hegemony by provider and absolute hegemonized toward laborer. The social economic impacts of hegemonic social relation are described as well, covering the social economic impacts toward both the hegemonizer parties and the hegemonized ones.

\section{Results and Discussion}

Hegemonic social relation in outsourcing practice is caused by some causes namely; (1) unlimited authority by the actor of user, (2) closed management by the provider, (3) less bargaining position toward laborer, and (4) loss of government intervention. The four causes effect patterns and forms of hegemonic social relation which covering; (a) abosolute hegemony by user toward both provider and laborer. The indications are the user has the right or authority to outsoutse (transfer) some kinds of job and the responsibility of job to external hand (provider). the user that determines a decision whether the transaction of transfer will be or will not be. Besides, the user also determines to continue or to stop the job relation with the provider. When the user still need the the business relation, the user will keep on the relation, but when the user do not need it, the user will stop it. User also hegemonizes laborer through the indication that user can intervene in laborer job activities. The user has right to manage and to command the laborer to do the user's commands. Even the user can threaten the laborers when they make mistakes in working. The threat is a written report which is made by the user for being given to the provider as the company of laborers that employs them and this report can cause a laborer to be stopped working. (b) semi- hegemony which is applicated by the provider. This means that, the provider has right to outsoure the laborer to any user company for being employed in order that the provider get profit. This profit is produced by taking a part of wage of laborer as the compensation and recompense. The profit also constitutes the result of work agreement between user company and the provider. Through this aggrement, user and provider agree with 
the cost or price of laborers. (c) absolute hegemonized toward laborer. This means that laborer is dominated or hegemonized by both user and provider. The user can use the laborer's work power and can freely direct the laborer in their work in the user's place without paying anymore. At the other hand, the provider has the right to outsource the laborer and offer the laborer to user company to be employed.

\section{Conclusion}

Hegemonic social relation in outsourcing practice in Makassar city constitutes a veiled power relation among actors of user, provider, and laborer. It is caused by some factors namely; the user has unlimited authority, the provider applicates closed management, less bargaining position toward laborer, and loss of government intervention in outsourcing practice in Makassar city. The power relation also forms patterns and types of relation which consist of absolute hegemony by user, semi-hegemony by provider, and absolute hegemonized toward laborer.

\section{References}

Foucault, Michel. 1987, The Ethic of Care for the Self as a Practice of Freedom, dalam James Bernauer dan David Rasmussen (Eds.) The Final Foucault. Boston: MIT Press.

Afandi, A.Khozin, 2011, Teosofi: Jurnal Tasawuf dan Pemikiran Islam Volume 01,Nomor 02

Gramsci, Antonio, 1978, Selections From the Prison Notebooks, International Publisher, New York.

Geishecker, Ingo, dan Gorg, Holger, 2004, International outsourcing and wages: Winners and losers, DIW Berlin and University of Nottingham danUniversity of Nottingham.

Jangyang Goo, dan kawan-kawan, 2007, An investigation of factors that influence The duration of IToutsourcing relationships, USA, Elsevier,Decision Support Systems.

Yasar, Iftida, 2012, Outsourcing Tidak Akan Pernah Dihapus, Jakarta, PT. Pelita Fikir Indonesia.

Beaumont, Nicholas, dan Sohal, Amrik, 2004, Outsourcing In Australia, Interna- tional Journal of Operations \& Production Management, Vol. 24 No. 7, pp. 688-700, Department of Management, Monash University, Caulfield East, Australia, Emerald Group Publishing Limited.

Martinsons, Maris G., 1993, Outsourcing Information Systems: A Strategic Partnership with Risks, Long Range Planning, Vol. 26, No. 3, pp. 18 to 25, Printed in Great Britain, 
Pergamon Press Ltd, Great Britain.

Tjandraningsih, Indrawati, Herawati, Rina dan Suhadmadi, 2010, Diskriminatif dan Eksploitatif, Bandung, Akatiga.

Juan Li, Julie, 2012, The alignment between organizational control mechanisms and Outsourcing strategies: A commentary essay, Journal of Business Research, Department of Marketing, City University of Hong Kong, Elsevier Inc.

Silaban, Rekson. 2009. Reposisi Gerakan Buruh, Peta Jalan Gerakan Buruh Indonesia Pasca Reformasi. Jakarta. Pustaka Sinar Harapan.

Suseno, Franz Magnis, 1999, Pemikiran Karl Marx, Dari Sosialisme Utopis ke Perselihan Revisionisme, Jakarta, PT. Gramedia Pustaka Utama.

Guba, E.G. dan Lincoln, Y.S., 1994, Competing Paradigm in Qualitative Research, dalam

N.K. Denzin dan Y.S. Lincoln (Eds.) Handbook of Qualitative Research. London: Sage Publications.

\section{Sumber Inspirasi}

Agustang, A. D. M. P., \& Agustang, A. (2021, December 15). Studi Politik Ekonomi Dalam Permulaan Wacana Development. https://doi.org/10.31219/osf.io/mx8gp

Tinri, M. D. N. (2018, June 26). Hotels and Restaurant Tax Revenues Management. https://doi.org/10.17605/OSF.IO/B8W7J

Agustang, A. (2021, January 10). INTERAKSI SOSIAL KOMUNITAS LOKAL DENGAN PENDATANG DAN PERUBAHAN STRUKTUR KOMUNITAS LOKAL (Studi pada Masyarakat Majemuk di Kawasan Industri Makassar). https://doi.org/10.31219/osf.io/pw5xr

Agustang, A., Ariani, A. I., \& Asrifan, A. (2021, January 10). KONSTRUKSI SOSIAL JANDA TEREKSPLOITASI (STUDI KASUS DI KELURAHAN TETEBATU KECAMATAN PALLANGGA KABUPATEN GOWA). https://doi.org/10.31219/osf.io/ryz2k

Agustang, A. (2021, January 22). Filosofi Research Dalam Upaya Pengembangan Ilmu. https://doi.org/10.31219/osf.io/9n6za

Kurniawan, A., \& Agustang, A. (2022, January 11). FAKTOR PENGHAMBAT TINGKAT KEDISIPLINAN SISWA DI SMAN 1 BANTAENG. https://doi.org/10.31219/osf.io/qnx 7z

Lestari, S. A., \& Agustang, A. (2022, January 11). EFEKTIVITAS PEMBELAJARAN ONLINE PADA MATA PELAJARAN SOSIOLOGI DI SMA NEGERI 22 MAKASSAR. https://doi.org/10.31219/osf.io/pgw8t

Quraisy, H., Agustang, A., \& Asrifan, A. (2022, January 11). MUHAMMADIYAH DALAM GERAKAN SOSIAL DI KABUPATEN WAJO. https://doi.org/10.17605/OSF.IO/ZWDN6 
Quraisy, H., Agustang, A., \& Asrifan, A. (2021, January 15). MUHAMMADIYAH DALAM GERAKAN SOSIAL DI KABUPATEN WAJO. https://doi.org/10.31219/osf.io/dpsg9

Oruh, S., Agustang, A., \& Asrifan, A. (2021, January 9). PENGARUH PENGETAHUAN KELUARGA, STIGMA MASYARAKAT DAN KEPATUHAN MINUM OBAT TERHADAP KEKAMBUHAN PENYAKIT GANGGUAN JIWA DI KOTA MAKASSAR. https://doi.org/10.31219/osf.io/wxsg8

Agustang, A., \& Oruh, S. (2021, January 22). Teknologi Partisipasi Metode Fasilitasi Pembuatan Keputusan Partisipatif. https://doi.org/10.31219/osf.io/dhfb7

Oruh, S., Agustang, A., \& Theresia, M. (2021, January 9). KESEJAHTERAAN PSIKOLOGIS (Studi Pada Dewasa Madya yang Belum Menikah di Kota Makassar). https://doi.org/10.31219/osf.io/v5af8

S., Agustang, A. D. M. P., \& Agustang, A. (2022, January 9). DINAMIKA PUTUS SEKOLAH DI KALANGAN PEKERJA ANAK DI KOTA MAKASSAR. https://doi.org/10.31219/osf.io/ucbz4

Agustang, A., Oruh, S., \& Mahmuddin, H. (2022, January 4). IMPROVING THE QUALITY OF PRIMARY HEALTH SERVICES IN THE PERSPECTIVE OF PARTICIPATORY GOVERNANCE. https://doi.org/10.17605/OSF.IO/9T8VQ

Oruh, S. (2022, January 4). STRATEGI PENGEMBANGAN SUMBER DAYA MASYARAKAT KEPULAUAN YANG UNGGUL MENUJU SOCIETY 5.0. https://doi.org/10.17605/OSF.IO/SP42D

Oruh, S. (2022, January 4). Supplemental materials for preprint: KAU MAU KEMANA (Refleksi Sosiologis terhadap Integritas Upaya Kesehatan Jiwa). https://doi.org/10.17605/OSF.IO/CP39Z

Oruh, S., \& Agustang, A. (2022, January 4). KESEJAHTERAAN PSIKOLOGIS (Studi Pada Dewasa Madya yang Belum Menikah di Kota Makassar). https://doi.org/10.17605/OSF.IO/ZUSKV

Oruh, S., \& Agustang, A. (2022, January 4). PENGARUH PENGETAHUAN KELUARGA, STIGMA MASYARAKAT DAN KEPATUHAN MINUM OBAT TERHADAP KEKAMBUHAN PENYAKIT GANGGUAN JIWA DI KOTA MAKASSAR. https://doi.org/10.17605/OSF.IO/K4VMP

Agustang, A., \& Oruh, S. (2022, January 4). HEGEMONIC SOCIAL RELATION A Study of Sociology on Outsourcing Practice. https://doi.org/10.17605/OSF.IO/PJM3A

Oruh, S., Agustang, A., \& Agustang, A. D. M. P. (2021, December 21). SOCIAL DETERMINANTS OF COMMUNITY HEALTH WITH THE EVENT OF DIABETES MELLITUS (Study of Health Sociology in Makassar City). https://doi.org/10.31219/osf.io/4qvxf

Tilome, A. A., Agustang, A. D. M. P., \& Agustang, A. (2021, December 16). PERTUKARAN SOSIAL ELIT POLITIK DALAM PEMILIHAN KEPALA DAERAH DI PROVINSI GORONTALO. https://doi.org/10.31219/osf.io/6tu79

Agustang, A., Ahriani, A., \& Asrifan, A. (2021, January 10). MARGINALISASI BUDAYA (STUDI PADA PRANATA SOSIAL MASYARAKAT MUSLIM SUKU KOKODA KOTA SORONG). https://doi.org/10.31219/osf.io/942y8 
Agustang, A., A, A. D. M. P., \& Asrifan, A. (2021, January 20). PERAN PENDIDIKAN DALAM MEMBANGUN KARAKTER BANGSA. https://doi.org/10.31219/osf.io/na9pu

Quraisy, H., Agustang, A., \& Asrifan, A. (2021, January 15). MUHAMMADIYAH DALAM GERAKAN SOSIAL DI KABUPATEN WAJO. https://doi.org/10.31219/osf.io/dpsg9

Agustang, A. (2021, January 10). KERAJINAN TENUN PADA MASYARAKAT MUNA (Kasus Peranan Modal Manusia dan Modal Sosial Dalam Reproduksi Budaya Tenun di Kabupaten Muna). https://doi.org/10.31219/osf.io/4bksf

Agustang, A., \& Oruh, S. (2021, January 22). Teknologi Partisipasi Metode Fasilitasi Pembuatan Keputusan Partisipatif. https://doi.org/10.31219/osf.io/dhfb7

Agustang, A. (1999). INTERAKSI SOSIAL DAN PERUBAHAN STRUKTUR KOMUNITAS. Universitas Padjadjaran Bandung.

Agustang, A. (2009). SIMBOLIKHAJI: Studi Deskriptif Analitik pada Orang Bugis. Al-Qalam, 15(2), 317-334.

Agustang, A. (2014). LIFE BEHAVIOR OF SOCIETY, FIVE CASES ON FAMILY OF DIABETES MELLITUS PATIENTS IN MAKASSAR. International Journal of Academic Research, 6(1).

Agustang, A. (2018). PERILAKU MEROKOK REMAJA SISWA SMA NEGERI 1 SINJAI UTARA KABUPATEN SINJAI. Jurnal Ilmiah Kesehatan Diagnosis, 13(1), 93-99.

Agustang, A. (2021). Teknologi Partisipasi Metode Fasilitasi Pembuatan Keputusan Partisipatif. OSF Preprints.

Agustang, A., \& Adam, A. (2020). INSTITUTIONAL FAILURES IN THE WORLD OF EDUCATION IN SCHOOLS FOR CHILDREN VICTIMS OF PARENTS. Asian Journal of Social Sciences \& Humanities, 9(2), $18-26$.

Agustang, A., \& Indah, A. M. (2021). Andi Asrifan. 2021.“. KONSTRUKSI SOSIAL JANDA TEREKSPLOITASI (STUDI KASUS DI KELURAHAN TETEBATU KECAMATAN PALLANGGA KABUPATEN GOWA)." OSF Preprints. January, 10.

Agustang, A., \& Mustafah, M. Y. (2017). METROSEKSUAL DIKOTA MAKASSAR.

Agustang, A., \& Oruh, S. (2021). KESEJAHTERAAN PSIKOLOGIS (studi Pada Dewasa Madya Yang Belum Menikah Di Kota Makassar).

Agustang, A., Saleh, S., Rasyid, R., \& Agustang, A. T. P. (2019). Pengembangan profesionalisme guru SMP Negeri 1 Duampanua Kabupaten Pinrang melalui pelatihan penulisan karya tulis ilmiah. Seminar Nasional Pengabdian Kepada Masyarakat, 2019(2).

Agustang, A., Suardi, S., Putra, A. D. M., \& Oruh, S. (2021). Pemberdayaan Guru Mata Pelajaran Sosiologi Melalui Literasi Digital Berbasis Quick 
Response Code di Kecamatan Bissappu Kabupaten Bantaeng. Abdi: Jurnal Pengabdian Dan Pemberdayaan Masyarakat, 3(2), 175-188.

Agustang, A. Y. A., Herman, H., Said, M., \& Agustang, A. (2021). Upaya Guru IPS Dalam Meningkatkan Motivasi Belajar Siswa Pada Masa Covid 19 Di SMP. Phinisi Integration Review, 4(1), 144-149.

Ahriani, A., Agustang, A., Adam, A., \& Upe, A. (2020). The Multiple Roles of Women in Poor.

Akbar, H., Oruh, S., \& Agustang, A. (2021). Indeks Prediktif Kejadian Demam Berdarah Dengue (DBD) Berbasis Perilaku Sosial Masyarakat Di Kabupaten Indramayu. Jurnal Kesehatan, 14(2 SE-), 76-82. https://doi.org/10.32763/juke.v14i2.289

Al Yakin, A., \& Agustang, A. (2020). SELEBRIFIKASI DAN ELEKTABILITAS; MENAKAR RESPON PUBLIK.

Alim, A., Agustang, A., \& Adam, A. (2021). Transformation of Consumption Behavior of the Poor in the Case of Malnutrition: Health Sociology Study with Participatory Approach in Makassar City, Indonesia. Open Access Macedonian Journal of Medical Sciences, 9(E), 598-607.

AM, S. A., Agustang, A., Mustadjar, M., \& Tahmir, S. (2020). Mobility and Social Change of the Economy of Indonesian Migrant Workers in Indonesia. Solid State Technology, 63(5), 408-417.

Aminah, S., Agustang, A., Idkhan, A. M., \& Rifdan, R. (2021). KUALITAS PELAYANAN PUBLIK PADA KANTOR PERTANAHAN KABUPATEN PANGKAJENE DAN KEPULAUAN. JISIP (Jurnal Ilmu Sosial Dan Pendidikan), 5(4).

Amran, N. G., \& Agustang, A. (2020). Implementasi Kurikulum 2013 Dalam Peningkatan Kompetensi Psikomotorik Dan Afektif Siswa. Phinisi Integration Review, 3(2), 179-184.

Andriana, Agustang, A., Idkhan, A. M., \& Hasriadi. (2021). Daya Tanggap Pelayanan Unit Gawat Darurat di Puskesmas Sarjo Kabupaten Pasangkayu . Journal Governance and Politics (JGP), 1(2 SE-Articles). https://e-journal.iyb.ac.id/index.php/jgp/article/view/201

Ardiansyah, A. A., \& Agustang, A. (2018). MAHASISWI BERKELUARGA DI FAKULTAS ILMU SOSIAL UNIVERSITAS NEGERI MAKASSAR. JURNAL SOSIALISASI, 19-23.

Aris, Agustang, A., \& Idkhan, A. M. (2021). Efektifitas Pelayanan Aparatur Sipil Dalam Meningkatkan Pelayanan Publik. Journal Governance and $\begin{array}{llll}\text { Politics } & \text { (JGP), } & 1(2 & \text { SE-Articles }) \text {. }\end{array}$ https://jurnal.iyb.ac.id/index.php/jgp/article/view/208

Arisal, A., Agustang, A., \& Syukur, M. (2020). Diskriminasi Sosial Anak Penderita Kusta di Kota Makassar. Phinisi Integration Review, 3(2), 297-304. 
Arpin, Agustang, A., \& Idkhan, A. M. (2021). Pengaruh Penerapan Model Dicovery Learning Terhadap Hasil Belajar Siswa Pada Mata Pelajaran IPA SD Inpres Tamalanrea V Kota Makassar. Journal Governance and Politics (JGP), $\quad 1(2 \quad$ SE-Articles $) . \quad$ https://ejournal.iyb.ac.id/index.php/jgp/article/view/204

Arwin, Agustang, A., Ihsan, A., \& Suhaeb, F. (2015). POVERTY AND MODERNIZATION IN BAJO FISHING COMMUNITY. International Journal of Academic Research, 7(Vol. 7. No. 3. May, 2015).

Asri, A., Kasnawi, T., \& Agustang, A. (2019). Actors' Social Tensions on Traditional Birth Attendants and Midwife Partnerships in Childbirth Assistance (Sociology of Health Study in Bulukumba Regency). IOSR Journal Of Humanities And Social Science (IOSR-JHSS), 24(Issue 1, Ser. 10), 20-27.

Aswan, A., \& Agustang, A. (2017). PERILAKU ANOMI (STUDI PADA SISWA DI SMP NEGERI 21 MAKASSAR). JURNAL SOSIALISASI, 62-66.

Azis, F., Idris, R., \& Agustang, A. (2017). Involution Fisheries: Post-Study Model of National Program in Integrated Movement at Community Fishermen's Village Development Arungkeke, Jeneponto. Mediterranean Journal of Social Sciences, $\quad 8(1 \quad$ SE-Articles $), \quad 441$. https://www.richtmann.org/journal/index.php/mjss/article/view/9713

Badwi, A., Agustang, A., \& Adam, A. (2018). Individual Cognitive Dissonance in Society on Condom (A Sociology of Health Study in Makassar City). IOSR Journal Of Humanities And Social Science (IOSR-JHSS), 23(Issue 8, Ver. 7), 14-19.

Badwi, A., Agustang, A., \& Adam, A. (2020). Individual Cognitive Dissonance in Society on Condom (A Sociology of Health Study in Makassar City).

Bastiana, B., Jumadi, J., Herman, H., \& Agustang, A. D. M. P. (2019). Pelatihan penulisan Penelitian Tindakan Kelas bagi guru SMP Negeri 1 Duampanua Kabupaten Pinrang. Seminar Nasional Pengabdian Kepada Masyarakat, 2019(2).

Bebang, M., \& Agustang, A. (2021). THE SOCIAL ACTION OF THE TEACHERS IN HANDLING INDISIPLINARY STUDENTS AT SMP NEGERI 36 MAKASSAR, SOUTH SULAWESI, INDONESIA. 20(5), 5792-5796. https://doi.org/10.17051/ilkonline.2021.05.652

Bebang, M., Agustang, A., \& Samad, S. (2021). THE SOCIAL ACTION OF THE TEACHERS IN HANDLING INDISIPLINARY STUDENTS AT SMP NEGERI 36 MAKASSAR, SOUTH SULAWESI, INDONESIA. Elementary Education Online, 20(5), 5792-5796.

Bintaha, M., Salman, D., Agustang, A., \& Suhaeb, F. W. (2014). THE ROLE OF SOCIAL CAPITAL TOWARD SOME OTHER CAPITALS FOR RURAL ADVANCEMENT. International Journal of Academic Research, 6(5). 
Burchanuddin, A., Agustang, A., Adam, A., \& Alim, A. (2021). Cultural Reproduction in the Socio-political Context of Bone District, South Sulawesi, Indonesia.

Daming, M., Agustang, A., Idkhan, A. M., \& Rifdan, R. (2021). IMPLEMENTASI KEBIJAKAN MAKASSAR RECOVER DALAM PENANGANAN COVID-19 DI KOTA MAKASSAR. JISIP (Jurnal Ilmu Sosial Dan Pendidikan), 5(4).

Dirawan, G. D. (2015). FOSTERING COLLABORATION STREET CHILDREN IN MAKASSAR. Man In India, 95(3), 569-576.

Djalante, A., Agustang, A., Tahmir, S., \& Sahabuddin, J. (2018). A Disadvantaged Tribe in Bajoe Village. Bone Regency: A Phenomenological Research on Bajo Tribe's Social Life in Bone Regency, South Sulawesi.

Djamaluddin, M., Agustang, A., Idkhan, A. M., \& Rifdan. (2021). Pengaruh Implementasi Corporate Social Responsibility PT. Vale Terhadap Kesejahteraan Hidup Masyarakat. Journal Governance and Politics $(J G P), \quad 1(2 \quad$ SE-Articles). https://jurnal.iyb.ac.id/index.php/jgp/article/view/200

Edyanto, E., Agustang, A., Idkhan, A. M., \& Rifdan, R. (2021). Implementasi Kebijakan Otonomi Khusus (Otsus) Papua. JISIP (Jurnal Ilmu Sosial Dan Pendidikan), 5(4).

Firdaus, F. (2017). Permandian Wae Pellae (Konstruksi Fisik Spasial dan Perubahan Masyarakat Sinjai). Equilibrium: Jurnal Pendidikan, 5(1), 15-20.

Hairuddin, Agustang, A., Manda, D., \& Jumadi. (2018). Dynamics of Social Behavior of Using Condoms in Brothel at Jalan Nusantara, Makassar City (Sociology of Health and Illness Review). IOSR Journal Of Humanities And Social Science (IOSR-JHSS), 23(Issue 3, Ver. 11), 3339.

Haniah, S., Agustang, A., \& Samad, S. (2014). SOCIAL ACTION IN THE CLASSROOM: ANALYSIS OF EDUCATIONAL SOCIOLOGY ON INTERACTION BETWEEN TEACHER AND STUDENT IN SMP KARTIKA CHANDRA MAKASSAR. International Journal of Academic Research, 6(4).

har, M., Agustang, A., Adam, A., \& Upe, A. (2021). Online Learning and Distortion of Character Education in the Covid-19 Pandemic Era. Webology, 18(Special Issue 04), 566-580. https://doi.org/10.14704/web/v18si04/web18149

Hariani, H., Oruh, S., \& Mustari, N. (2021). GAMBARAN POLA ASUH ANAK PADA IBU YANG BEKERJA DI KELURAHAN KARANG ANYAR KOTA MAKASSAR. Media Keperawatan: Politeknik Kesehatan Makassar, 12(1), 1-6. 
Harman, H., \& Agustang, A. (2020). PERUBAHAN SOSIAL MASYARAKAT PERMANDIAN WAE TUO DESA WAE TUO KECAMATAN KAJUARA KABUPATEN BONE. Jurnal Sosialisasi: Jurnal Hasil Pemikiran, Penelitian Dan Pengembangan Keilmuan Sosiologi Pendidikan, 2, 1-7.

Hermansya, H. (2014). Pengaruh kompetensi profesional guru sosiologi Terhadap Hasil Belajar Ssiswa di SMA Negeri 1 Soppeng Riaja Kabupaten Barru. Skripsi. Dibimbing oleh Prof. Dr. Andi Agustang, M. Si dan H. Dr Muhammad syukur, M, Si. Program Studi Pendidikan Sosiologi Fakulta. universitas negeri makassar.

Hikmah, N., \& Agustang, A. (2017). PERAN POST TEST TERHADAP MOTIVASI BELAJAR PADA MATA PELAJARAN SOSIOLOGI SISWA DI SMA NEGERI 11 MAKASSAR. JURNAL SOSIALISASI.

HIKMAH, N., \& AGUSTANG, A. (2016). PERAN POST TEST TERHADAP MOTIVASI BELAJAR SISWA PADA MATA PELAJARAN SOSIOLOGI DI SMA NEGERI 11 MAKASSAR. Universitas Negeri Makassar.

Idrus, I. I., Salman, D., \& Agustang, A. (2021). Commodification of Environmental Discourse in the Process of Producing Space in Bukit Baruga Housing, Makassar. IOP Conference Series: Materials Science and Engineering, 1125(1), 12087.

Irwan, A. A., Adam, A., \& Upe, A. (2021). Community Empowerment Strategy towards a Sustainable Rural Community-based Tourısm Village. Turkish Online Journal of Qualitative Inquiry (TOJQI), 12(5), 2065-2076.

Ismanto, Agustang, A., \& Idkhan, A. M. (2021). Pengaruh Kompensasi Finansial Terhadap Produktivitas Kerja Karyawan Pada PT PLN (PERSERO) Rayon Makassar Barat. Journal Governance and Politics (JGP), 1(2 SEArticles). https://e-journal.iyb.ac.id/index.php/jgp/article/view/202

Jumadi, Nurlela, Agustang, A., \& Darman. (2020). Social Actions of Galla Actors in the Kaemba Maros Traditional Village Community Sulawesi Selatan. 3rd International Conference on Social Sciences (ICSS 2020), 748-753.

Jumharyanti, J., \& Agustang, A. (2018). REMITANSI TENAGA KERJA INDONESIA PASCA KEPULANGAN DARI LUAR NEGERI (STUDI TKI DI DESA WORO KECAMATAN MADAPANGGA KABUPATEN BIMA NTB). Jurnal Sosialisasi: Jurnal Hasil Pemikiran, Penelitian Dan Pengembangan Keilmuan Sosiologi Pendidikan, 68-73.

Kasnawi, T., \& Agustang, A. (2014). TRADITIONAL ELITE ON MODERN POLITICS AT SOUTH SULAWESI. International Journal of Academic Research, 6(4).

Khaerun, K. (2014). Khaerun. Pengaruh kemampuan Manajerial Kepala Madrasah dan Kompetensi Pedagogik terhadap Kinerja Guru di Madrasah Tsanawiyah Kabupaten Gowa Provinsi Sulawesi Selatan.(Dibimbing oleh Andi Agustang dan Jumadi Tangko). universitas 
negeri makassar.

Kubangun, N., Agustang, A., \& Adam, A. (2020). Subaltern and Network Strategy Towards Fishermen Community in Aru Islands District. 3rd International Conference on Social Sciences (ICSS 2020), 585-588.

LEGIYO, L., Agustang, A., \& Hakim, M. (2018). Relasi Punggawa dan Sawi pada Bagan Perahu (Studi Kasus Nelayandi Pulau Balang Lompo Kabupaten Pangkep). UNIVERSITAS NEGERI MAKASSAR.

Leiwakabessya, J. E. M., Kasnawi, M. T., \& Agustang, A. (2021). The reality of the conflict of customary lands between the land of laha and the air force in ambon city (case study customary land in the land of laha). Turkish Online Journal of Qualitative Inquiry (TOJQI), 12(09), 4797-4804.

Makmur, M. A., Agustang, A., \& Idkhan, A. M. (2021). Tingkat Kepuasan Masyarakat Terhadap Pelayanan Publik (Evaluasi Implementasi Program Beras Sejahtera Di Kota Palopo). Jurnal Sosio Sains, 7(2), 131-138.

Masita, M., \& Agustang, A. (2020). Pergeseran Pemaknaan Perayaan Tradisi Saiyyang Pattu'duq di Tinambung Polewali Mandar. Phinisi Integration Review, 3(2), 173-178.

Mufidah, N. F., \& Agustang, A. (2020). STUDI SOSIOLOGI PERNIKAHAN MUBARAK DI PONDOK PESANTREN HIDAYATULLAH MAKASSAR. Jurnal Sosialisasi: Jurnal Hasil Pemikiran, Penelitian Dan Pengembangan Keilmuan Sosiologi Pendidikan, 1, 1-8.

Muhammad, S., Agustang, A., \& Samad, S. (2015). SOCIAL MOVEMENT IN A MINING PROJECT: A STUDY OF SOROWAKOAN CONTENTIOUS POLITICS TOWARDS PT VALE INDONESIA, TBK. IN SOROWAKO, SOUTH SULAWESI. International Journal of Academic Research, 7(Issue ID: IJ15V7N3).

Muis, I., Agustang, A., \& Adam, A. (2020). Lansia Miskin: Demografi Sosial, Distribusi Pekerjaan, Masalah Kesehatan \& Perlindungan Sosial.

Mukti, I., Oruh, S., \& Agustang, A. (2021). Efek Pemberitaan Kekerasan Di Media Sosial Terhadap Citra Negatif Kota Makassar. JISIP (Jurnal Ilmu Sosial Dan Pendidikan), 5(4).

Muslimin, A., Idris, R., \& Agustang, A. (2015). CHILDREN AND SOCIAL ENVIRONMENT OF EDUCATION. International Journal of Academic Research, 7.

Mustadjar, M., \& Agustang, A. (2020). Pergeseran Pola Interaksi Sosial (Studi Pada Masyarakat Banggae Kabupaten Majene). Phinisi Integration Review, 3(2), 138-149.

Nismawati, N., Oruh, S., \& Agustang, A. (2021). Eksistensi Tari Kabasaran Pada Masyarakat Minahasa. Jurnal Ilmiah Mandala Education, 7(4).

Nonci, N., Salman, D., \& Agustang, A. (2014). SILARIANG: STUDY OF THE 
SOCIAL CONSTRUCTION OF ETHNIC IN MAKASSAR IN GOWA DISTRICT. International Journal of Academic Research, 6(1).

Nur, S., Andi Agustang, \& Arlin Adam. (2020). Uninhabitable Home: Portraits of Poverty in Cities. Indonesian Journal of Social and Environmental Issues (IJSEI), 1(3 SE-), 234-238. https://doi.org/10.47540/ijsei.v1i3.81

Nurbaety, A., Torro, S., \& Agustang, A. (2015). REDUKSI PERAN GOLONGAN BANGSAWAN BUGIS DALAM KEHIDUPAN SOSIAL DI DESA SANREGO KECAMATAN KAHU. FIS.

Nurdin, N., Salman, D., Agustang, A., \& Malago, J. (2021). The Effect of Social Support and Gratitude on Resilient Persons with Disabilities in Makassar City. IOSR Journal of Humanities And Social Science (IOSR-JHSS), 12(5), 14-21.

Nursafitra, M., Agustang, A., Idkhan, A. M., \& Nurwiwiana. (2021). Pengaruh Disiplin Kerja dan Komitmen Organisasi Terhadap Kinerja Pegawai di Kantor Dinas Kependudukan dan Pencatatan Sipil Kabupaten Enrekang. Journal Governance and Politics (JGP), $1(2$ SE-Articles). https://jurnal.iyb.ac.id/index.php/jgp/article/view/203

Nursinah, Agustang, A., Adam, A., \& Bastiana. (2021). RELAPSE BEHAVIOR OF NAPZA ABUSE AFTER REHABILITATION IN MAKASSAR CITY. PalArch's Journal of Archaeology of Egypt/Egyptology, 18(08), 1845-1854.

Oruh, S. (2021). Analisis faktor Keaktifan Kader dalam Kegiatan Posyandu. Jurnal Ilmiah Kesehatan Sandi Husada, 10(1), 319-325.

Oruh, S., \& Agustang, A. (2019). Pengaruh Pengetahuan Keluarga, Stigma Masyarakat dan Kepatuhan Minum Obat Terhadap Kekambuhan Penyakit Gangguan Jiwa di Kota Makassar. 53(9). https://doi.org/10.1017/CBO9781107415324.004

Oruh, S., \& AGUSTANG, A. (2019). PENGARUH PENGETAHUAN KELUARGA, STIGMA MASYARAKAT DAN KEPATUHAN MINUM OBAT TERHADAP KEKAMBUHAN PENYAKIT GANGGUAN JIWA DI KOTA MAKASSAR.

Oruh, S., Agustang, A., \& Bagu, A. A. (2017). KEJADIAN HEROPNAM GANGGUAN JIWA DAN FAKTOR YANG MEMPENGARUHI PADA RUMAH SAKIT KHUSUS DAERAH DADI PROVINSI SULAWESI SELATAN.

Oruh, S., Agustang, A., \& Bagu, A. A. (2020). KEJADIAN HEROPNAM GANGGUAN JIWA DAN FAKTOR YANG MEMPENGARUHI PADA RUMAH SAKIT KHUSUS DAERAH DADI PROVINSI SULAWESI SELATAN.

Oruh, S., \& Nur, H. (2021). Perilaku Masyarakat Pesisir di Hutan Mangrove Desa Balangdatu Kabupaten Takalar. Phinisi Integration Review, 4(2), 292- 
300.

Oruh, S., Theresia, M., \& Agustang, A. (2019). KESEJAHTERAAN PSIKOLOGIS. Researchgate.Net.

Pettalongi, A., Idris, R., Kasnawi, T., \& Agustang, A. (2015). PROMOTING SOCIAL VALUES IN BUILDING SOCIAL INTERACTION AMONG INTER-ETHNICAL STUDENTS IN SMA KARUNA DIPA, PALU. International Journal of Academic Research, 7.

Rachim, A., Lolo, T. R. A., \& Agustang, A. (2017). RELATIONS AUTHORITY.

Rahman, B., Agustang, A., \& Samad, S. (2015). HEGEMONIC SOCIAL RELATION, A STUDY OF SOCIOLOGY ON OUTSOURCING PRACTICE. International Journal of Academic Research, 7.

Rahman, N., Agustang, A., Akib, H., \& Tahmir, S. (2015). ANALYSIS OF THE DETERMINANT FACTORS OF IN THE LEGISLATIVE PROCESS OF REGIONAL HOUSE OF PEOPLES'REPRESENTATIVES IN TAKALAR REGENCY. International Journal of Academic Research, 7.

RAHMAN, S. (2014). Industri Pabrik dan Masyarakat Lokal di Pinggiran Kota Makassar: Kasus Dua Komunitas Desa Sekitar PT. Kawasan Industri Makassar,(dibimbing oleh HM Idrus Abustam, Andi Agustang dan H. Heri Tahir). universitas negeri makassar.

Ramlafatma, R., Oruh, S., \& Agustang, A. (2021). Efektivitas Pendidikan Moral Dalam Pembentukan Karakter Siswa Di TK Islam Terpadu Asa Sumbawa. Jurnal Ilmiah Mandala Education, 7(4).

Rasyid, D., Agustang, A., Syukur, M., Usman, S., \& Marzuki, M. (2021). Social Transformation of Indonesian Older Adults in Suburbs: An Exploratorydescriptive Qualitative Study. Ethno Med, 15((1-2)), 44-52.

Rasyid, R., Agustang, A., Agustang, A. T. P., Bastiana, B., \& Najamuddin, N. (2020). Analisis Faktor Yang Mempengaruhi Status Kemiskinan Rumah Tangga Pada Wilayah Central Bussiness District (CBD) di Kota Makassar. Majalah Geografi Indonesia, 34(1), 43-52.

Rieuwpassa, S., Agustang, A., \& Adam, A. (2020). Sustainable Peace Development In Ambon (An Analysis Study In Negeri Hila And Dusun Hila Tanah Putih). INTERNATIONAL JOURNAL OF SCIENTIFIC \& TECHNOLOGY RESEARCH, 9(2), 477-480.

Risal, R., Agustang, A., \& Syukur, M. (2021). Peranan Perempuan Tani dalam Meningkatkan Ekonomi Keluarga di Kelurahan Bonto Langkasa Kecamatan Bissappu Kabupaten Bantaeng. Phinisi Integration Review, $4(2), 282-291$.

Rongrean, B., Abustan, I., \& Agustang, A. (2015). THE SOCIAL DYNAMICS OF PEDICAB DRIVER TOWARD CLIMATE CHANGES IN MAKASSAR. International Journal of Academic Research, 7. 
Rusli, M., Bulkis, S., \& Agustang, A. (2018a). MAKNA PERAN DAN MODAL SOSIAL PEREMPUAN NELAYAN BAJO (Studi Fenomenologi di Pesisir Pantai Soropia Kabupaten Konawe). UNIVERSITAS NEGERI MAKASSAR.

Rusli, M., Bulkis, S., \& Agustang, A. (2018b). Usage of Social Capital in Supporting the Welfare of the Coastal Community. IOSR Journal Of Humanities And Social Science (IOSR-JHSS), 23(Issue 8, Ver. 2), 26-32.

Saeni, R., \& Agustang, A. (2014). INDUSTRIAL FACTORY AND LOCAL COMMUNITIES ON THE MARGINAL CITY OF MAKASSAR. International Journal of Academic Research, 6(4).

Safar, M., Agustang, A., \& Adam, A. (2017). PSEUDO AKTOR POLITIK (Studi Genealogi Kekuasaan di Sulawesi Tenggara Indonesia). Pascasarjana.

Sahabuddin, A., Agustang, A., \& Idkhan, A. M. (2021). Fungsi Leadership dalam Peningkatan Pelayanan Publik di Kantor Kecamatan Makassar. Journal Governance and Politics (JGP), $1(2 \quad$ SE-Articles). https://jurnal.iyb.ac.id/index.php/jgp/article/view/207

Sahabuddin, E., Agustang, A., Manda, D., \& Oruh, S. (2020). Partisipasi Sosial Dalam Pemenuhan Activity Daily Living (Adl) Orang Dengan Gangguan Jiwa Di Kota Makassar. Phinisi Integration Review, 3(2).

Salmah, A. U., Idris, R., Agustang, A., \& Maidin, A. (2013). Socio-Cultural Transformation of Early Detection on Breast Cancer Suspect in Wahidin iSudirohusodo Hospital, Makassar Indonesia.

Samanlangi, A. I., Agustang, A., Adam, A., \& Alim, A. (2021). Disconnectivity Social of Conflict in the Circle of Iron Ore Mine in Bone Regency, South Sulawesi, Indonesia. International Journal of Criminology and Sociology, 10, 963-973.

Sanusi, D., Agustang, A., \& Idkhan, A. M. (2021). Pengembangan Sumber Daya Manusia Dalam Meningkatkan Pelayanan Akademik Di Universitas Puangrimaggalatung Sengkang $\begin{array}{llll}\text { Politics } & (J G P), & 1(2 & \text { SE-Articles). }\end{array}$ https://jurnal.iyb.ac.id/index.php/jgp/article/view/205

Sapulette, A. A., Agustang, A., \& Syukur, M. (2018). Actor Construction in the Frame of Diversity to Achieve Social Harmony in the Life of Tamilouw Village Society Seram Island-Maluku. IOSR Journal Of Humanities And Social Science (IOSR-JHSS), 23(Issue 2, Ver. 4), 54-60.

Suardi, Agustang, A., \& Jumadi. (2020). A., \& Jumadi.(2020b). The Symbolic Violence Towards Private School Students Through The Frame Stereotype In Bantaeng District Of Indonesia. The International Conference on Innovations in Social Sciences and Education, 578-588.

Suardi, Agustang, A., \& Jumadi. (2021a). DOMINATION OF THE POWER OF QUALITY AND QUANTITY OF STATE SCHOOL EDUCATION 
AGAINST PRIVATE SCHOOLS AS FACTORS CAUSING SYMBOLIC VIOLENCE OF STUDENTS IN BANTAENG DISTRICT. PROCEEDING 1st INTERNATIONAL CONFERENCE (On Health, Education, and Computer Science Technology), 1(pertama), 246-259.

Suardi, S., Agustang, A., \& Jumadi, J. (2021b). Dominasi Sekolah Negeri Terhadap Sekolah Swasta Sebagai Penyebab Kekerasan Simbolik Terhadap Siswa Sekolah Swasta. Jurnal Ilmiah Muqoddimah: Jurnal Ilmu Sosial, Politik Dan Hummanioramaniora, 5(2).

Sulaiman, U., Idris, R., Ardi, M., \& Agustang, A. (2014). The Pattern of Cooperation and Poorness: A Seaweed Farming Community in Indonesia. International Journal of Academic Research, 6(5), 239-242.

Sumai, S., Agustang, A., Adam, A., \& Obie, M. (2020). Resilience in Children of Drug Abuse Families: A Case in Pattingalloang, Makassar City, Indonesia.

Sumitro, S., Oruh, S., \& Agustang, A. (2021). Eksistensi Nilai Sosial Budaya Ndeu Paki Oi Mbaru Pada Masyarakat Donggo Kabupaten Bima. Jurnal Ilmiah Mandala Education, 7(4).

Suparman, Oruh, S., \& Agustang, A. (2021). Dinamika Sosial Kelompok Tani (Studi Kasus Petani Bawang Merah Desa perangian Kecamatan Baraka Kabupaten Enrekang). JIIP-Jurnal Ilmiah Ilmu Pendidikan, 4(6), 406414.

Sutrisno, S., \& Agustang, A. (2018). Peranan Pengawas Sekolah Terhadap Pelaksanaan Kurikulum 2013 Di SMA Negeri 17 Makassar. Jurnal Sosialisasi: Jurnal Hasil Pemikiran, Penelitian Dan Pengembangan Keilmuan Sosiologi Pendidikan, 100-105.

Syaharuddin, S., Agustang, A., Idkhan, A. M., \& Rifdan, R. (2021). STRATEGI DINAS SOSIAL DALAM PENANGANAN ANAK JALANAN DI KOTA MAKASSAR. JISIP (Jurnal Ilmu Sosial Dan Pendidikan), 5(4).

Syamsul, A. (2014). Remaja penjajah seks komersial kota Makassar. Skripsi Sosiologi, Fakultas Ilmu Sosial, Universitas Negeri Makassar, yang di bimbing oleh. Firdaus W. Suhaeb sebagai pembimbing satu dan Andi Agustang sebagai pembimbing dua. universitas negeri makassar.

Syamsul, B., Idrus, A., Jumadi, S., \& Edwar, P. (2014). "A'PA ALLIRI”: THE SOCIAL FUNCTION OF LOCAL INSTITUTION AT MATAJANG SOCIETY. INTERNATIONAL JOURNAL of ACADEMIC RESEARCH, 6(6), 121-125.

Syukurman, S., Agustang, A., \& Adam, A. (2020). Peluang dan Tantangan Lembaga Pendidikan Islam (Ditinjau dari Sosiologi Agama di Desa Doridungga). EDU SOCIATA (Jurnal Pendidikan Sosiologi), 3(2), 7187.

Thamrin, M., Agustang, A., Adam, A., \& Alim, A. (2021). Disruption of Stunting 
Social Capital in South Sulawesi, Indonesia (Case Study on 1000FDL Families in Bone and Enrekang Districts). Indian Journal of Public Health Research \& Development, 12(2).

Tinri, M. D. N. (2018). Hotels and Restaurant Tax Revenues Management.

Triono, T., Agustang, A., Idkhan, A. M., \& Rifdan, R. (2021). Motivasi Kerja Pegawai Dalam Pelayanan Publik. JISIP (Jurnal Ilmu Sosial Dan Pendidikan), 5(4).

Ufie, A., Oruh, S., \& Agustang, A. (2021). Maintaining Social Harmony Through Historical Learning Based on Local Wisdom of Indigenous Peoples in Maluku. Historia: Jurnal Pendidik Dan Peneliti Sejarah, 5(1), 31-40.

UMAR, S. (2014). Pola Kerjasama dan Ketidaksejahteraan Komunitas Petani Rumput Laut di Kecamatan Ujung Loe Kabupaten Bulukumba (Dibimbing oleh Promotor Rabihatun Idris serta Kopromotor Muhammad Ardi dan Andi Agustang). universitas negeri makassar.

Urbach, N., \& Agustang, A. (2019). PREFERENSI ORANG TUA DALAM MENYEKOLAHKAN ANAKNYA DI DESA AMOLA KECAMATAN BINUANG KABUPATEN POLEWALI. JURNAL SOSIALISASI, 89-94.

Usman, A., Agustang, A., \& Idkhan, A. M. (2021). Penerapan Pelayanan Prima di Rumah Sakit Paru BBPM Makassar. Journal Governance and Politics $(J G P), \quad 1(2 \quad$ SE-Articles). https://jurnal.iyb.ac.id/index.php/jgp/article/view/206

Wardah, S., Salman, D., Agustang, A., \& Fahmid, I. M. (2017). The Contestation of Organic and Non-Organic Agricultural Knowledge in Sustainable Agriculture. Mediterranean Journal of Social Sciences, 8(2 SE-Articles), 245.

https://www.richtmann.org/journal/index.php/mjss/article/view/9883

Wardiani, I., \& Agustang, A. (2018). Dampak Pekerjaan Orang Tua Pengrajin Emas Terhadap Pendidikan Anak di Kelurahan Borong Kecamatan Manggala Kota Makassar. UNIVERSITAS NEGERI MAKASSAR.

Wihdania, W., \& Agustang, A. (2020). Pernikahan Tolotang Di Kelurahan Amparita Kecamatan Tellu Limpoe Kabupaten Sidenreng Rappang. Phinisi Integration Review, 3(2), 165-172.

WULAN, S. (2014). Peranan Media Pembelajaran Dalam Meningkatkan Motivasi Belajar Sosiologi Pada Siswa SMA PGRI Galesong. Skripsi. Dibimbing oleh Andi Agustang dan Hj. Musdaliah Mustadjar Program Studi Pendidikan Sosiologi. Fakultas Ilmu Sosial, Universitas Negeri Makassar. universitas negeri makassar.

Yakobus, I. K., Kasnawi, T., Agustang, A., \& Gani, H. A. (2019). Hybridization of the Poso Conflict Resolution Discourse.

Yudhar, A. N., Agustang, A., \& Sahabuddin, J. (2021). Habituation of character values in junior high school students. Cypriot Journal of Educational 
Sciences, 16(2), 659-668.

Yusuf, M., Agustang, A., Idkhan, A. M., \& Rifdan, R. (2021). Transformasi Lembaga Koperasi Di Era Industri 4.0. JISIP (Jurnal Ilmu Sosial Dan Pendidikan), 5(4). 